\title{
FROM "PAPER PARK" TO MODEL PROTECTED AREA: THE TRANSFORMATION OF IKH NART NATURE RESERVE, MONGOLIA
}

\author{
* Corresponding Author: rpreading@gmail.com \\ ${ }^{1}$ University of Denver, USA \\ 2 Mongolian Conservation Coalition, Mongolia \\ ${ }^{3}$ University of Vermont, USA \\ ${ }^{4}$ National University of Mongolia, Mongolia \\ ${ }^{5}$ Nottingham Trent University, UK \\ 6 Anza-Borrego Desert State Park, USA \\ 7 Mongolian Academy of Sciences, Mongolia \\ 8 California State Parks, USA \\ ${ }^{9}$ Anza Borrego Foundation, USA \\ ${ }^{10}$ Denver Zoological Foundation, USA
}

Richard P. Reading ${ }^{1,2^{*}}$, James D. Murdoch ${ }^{3}$, Sukh Amgalanbaatar ${ }^{2}$, Suuri Buyandelger ${ }^{4}$, Hannah Davie ${ }^{5}$, Mark Jorgensen ${ }^{6}$, David Kenny ${ }^{2}$, Tserendorj Munkhzul ${ }^{7}$, Ganbold Onloragcha ${ }^{2}$, Lynn Rhodes ${ }^{8,9}$, Joan Schneider ${ }^{9}$, Tuvendorj Selenge ${ }^{2}$, Erin Stotz ${ }^{10}$ and Ganchimeg Wingard ${ }^{2,10}$

\begin{abstract}
Protected areas represent the most effective form of biodiversity conservation; however, many remain poorly managed and some exist only on paper without management - called "paper parks". We describe our collective efforts to transform Ikh Nart Nature Reserve (Ikh Nart) in Mongolia from a paper park into a model protected area. Resource constraints and lack of capacity precluded active management prior to our project. This paper outlines the process that ultimately led the United Nations Development Programme to designate Ikh Nart as a model protected area. Five overlapping and complementary aspects of our work included: 1) rigorous research; 2) a management structure, plan and process; 3) building local capacity; 4) cultivating local support; and 5) creating sustainable administrative policies and funding. Our efforts resulted in several successes, including reserve expansion, increases in wildlife populations, and strong local support. The lessons learned in Ikh Nart may offer guidance for protected area development in other areas.
\end{abstract}

Key words: Capacity building, community-based conservation, Gobi, paper park, park management, steppe, wildlife

\section{INTRODUCTION}

Protected areas represent the most effective form of biodiversity conservation (Bruner et al., 2001; Dudley et al., 2014; Kellett, 2015; Taylor, 2015). Yet, many protected areas become established prior to acquiring adequate knowledge of the ecology of the natural communities they hope to conserve (Wuerthner, 2015). In addition, park boundaries usually result from a compromise between human desires to use natural resources, such as timber, minerals and forage for livestock, and to protect natural heritage. As a result, protected areas often fail to protect key habitats (Terborgh, 2015). Some countries, and not only developing countries, also often establish protected areas before they acquire the capacity to adequately manage those areas, resulting in so-called "paper parks" that exist only in government documents (Reading et al., 1999, 2015; Taylor, 2015). Paper parks receive little to no active management and are usually unknown to local people. Effective conservation requires transforming such paper parks into actual reserves characterized by active law enforcement, the presence of a management plan and staff to implement the plan, and a supportive local population (Taylor, 2015).

This paper describes our approach and efforts to transform Ikh Nart Nature Reserve in Mongolia from a paper park into a model protected area that can be used as a case study to improve management of other protected areas in Mongolia and elsewhere. 


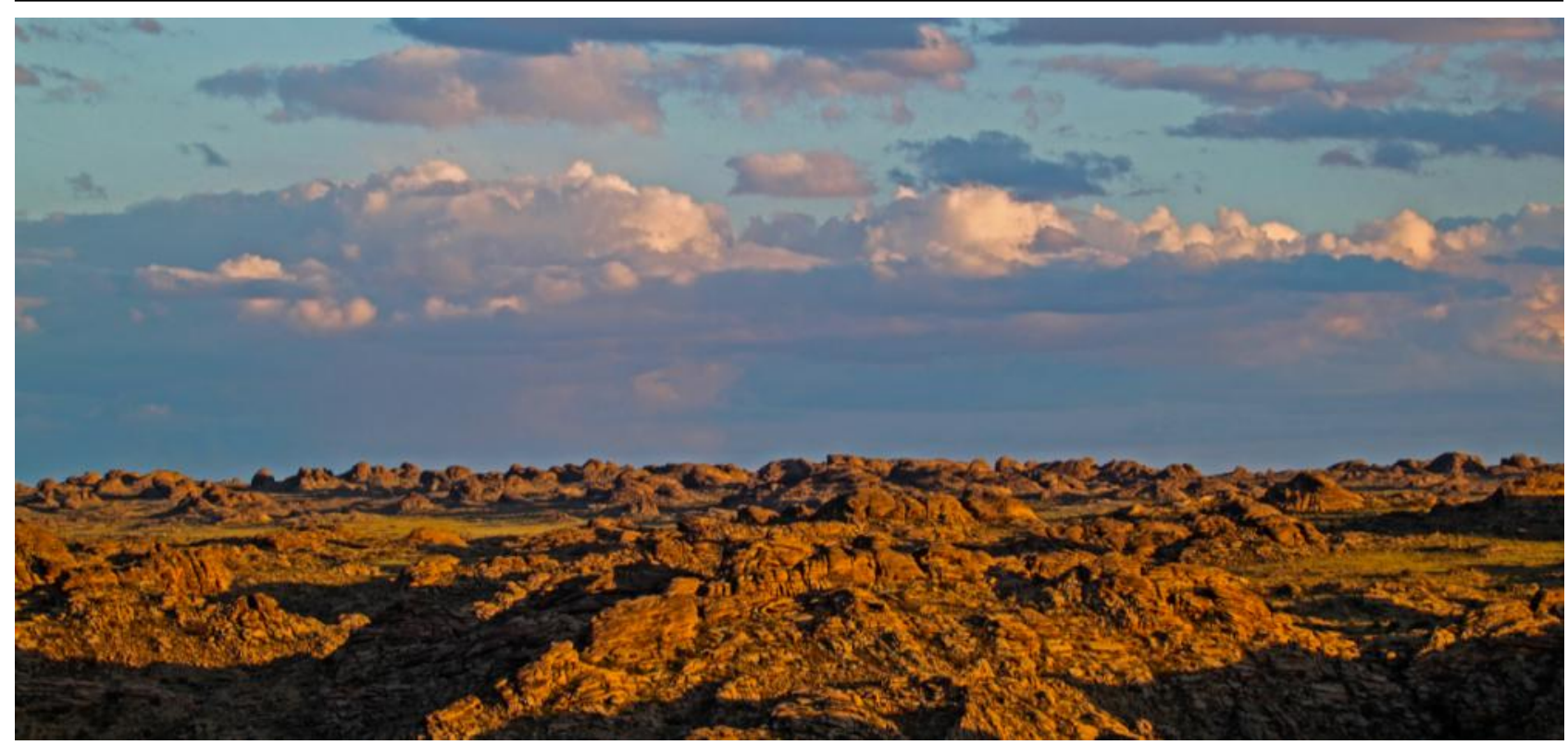

Rocky outcrops of Ikh Nart Nature Reserve, Mongolia @) Richard Reading

\section{BACKGROUND}

Mongolia rapidly transitioned from a communist country with a command-control economy to a democracy with a capitalist economy following the collapse of the Soviet Union in the early 1990s. During the transition, Mongolia adopted an ambitious goal of placing 30 per cent of its land area under state protection (Reading et al., 1999). In the mid-1990s, Mongolia moved aggressively to establish protected areas, going from protection of about 3.5 to 12 per cent of its land area within just a few years (Reading et al., 1999). These areas included Strictly Protected Areas, National Conservation Parks, Nature Reserves and National Monuments (Reading et al., 2015). Since then, expansion has slowed as natural resource extraction interests began to dominate the national economy, resulting in land use policies driven by exploration and extraction of minerals such as copper and gold. As of 2012, mining and drilling companies had leased, applied for leases, or were open to lease about 45 per cent of Mongolia, with tender bids (areas open for a lease bid) accounting for about half of the 45 per cent (Reading et al., 2015). Still, by 2012, the national government had protected over 17 per cent of Mongolia, with provincial (aimag) and county (soum) local governments protecting an additional 10 per cent or so countrywide (Reading et al., 2015).

Resource constraints and lack of capacity precluded active management of many protected areas in Mongolia immediately following creation. As management began and ecologists initiated research, gaps in protection have become evident. Our project began in Ikh Nart Nature Reserve (hereafter Ikh Nart) in 2000, four years after its establishment and prior to active management (Reading et al., 2011). Since then, studies have examined Ikh
Nart's biota, and human attitudes and values, land use practices, and culture to serve as a knowledge base for management (e.g., Jackson et al., 2006; Reading et al., 2003, 2011; Davie et al., 2014a). Simultaneously, management activities started, including funding law enforcement officers, education and outreach, livelihood enhancement, cultural resource protection, and naturebased tourism development working closely with local people and governments responsible for Ikh Nart. Under Mongolian law, local governments have management authority over nature reserves and national monuments, yet the relationship between those governments and the national government with respect to protected areas remains unclear in the law (Wingard \& Odgerel, 2001). The lack of legal clarity over management complicates conservation efforts.

Our research results indicated that a substantial amount of important habitat used by Ikh Nart's wildlife occurred outside the reserve's boundaries (e.g., Reading et al., 2003, 2005a, 2005b, 2010b; Murdoch et al., 2013, 2016; Lkhagvasuren et al., 2016). To their credit, when presented with these data, Dalanjargalan and Airag soums established local protected areas contiguous with Ikh Nart to protect these habitats, effectively expanding the reserve (S. Amgalanbaatar, pers. commun.). This paper discusses the process that resulted in Ikh Nart's expansion and effective management, which ultimately culminated in the United Nations Development Programme (UNDP) designating Ikh Nart as a model protected area under its Strengthening Protected Areas Network (SPAN) project funded by the Global Environment Facility (GEF). The authors hope this approach may offer guidance for protected area development in other parts of Mongolia and the world. 


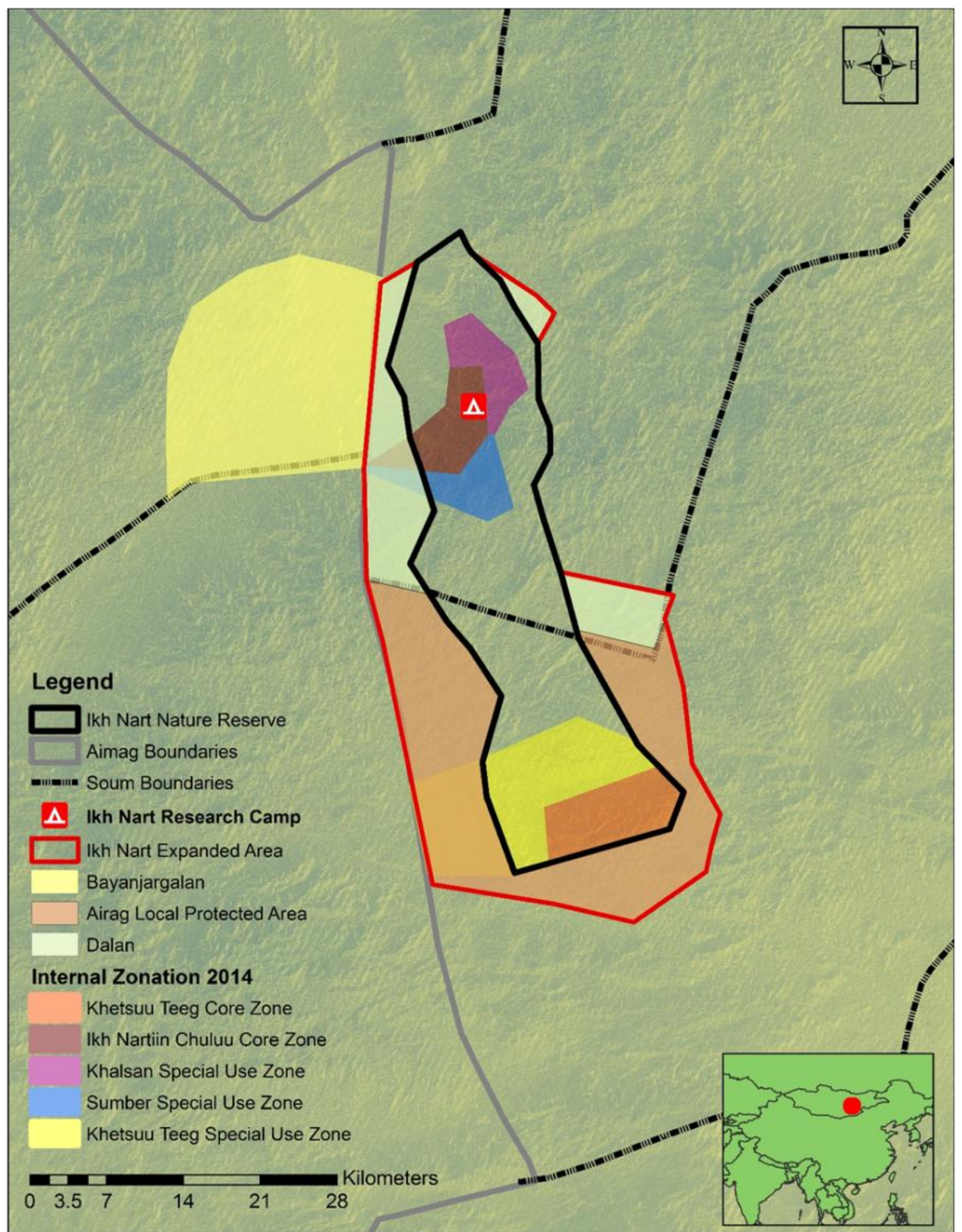

Figure 1. Location of Ikh Nart Nature Reserve, Dornogobi Aimag, Mongolia relative to soum and aimag boundaries showing the distribution of major habitat types and roads.

\section{STUDY AREA}

Ikh Nart Nature Reserve lies in north-eastern Dornogobi Aimag (centred about $45^{\circ} 43^{\prime} \mathrm{N}, 108^{\circ} 39^{\prime} \mathrm{E}$ ), on the northern edge of the Gobi Desert ecosystem at the transition between steppe and desert habitats (Figure 1; Reading et al., 2011). Established in 1996 to protect approximately $666 \mathrm{~km}^{2}$ of rocky outcrops and native wildlife, especially argali sheep (Ovis ammon), Ikh Nart contains sparse vegetation at the interface of dry steppe and semi-desert steppe ecotypes. Vegetation types include shrublands, tall grasslands, and open plains of short grasses, forbs and semi-shrubs (Jackson et al., 2006). Given Ikh Nart's location at the transition between ecotypes, a relatively wide variety of species inhabit the reserve (Reading et al., 2011). Topography ranges from gently rolling plains to areas with rugged rocky outcrops and steep drainages, some with ephemeral or permanent cold water springs. Ikh Nart has 


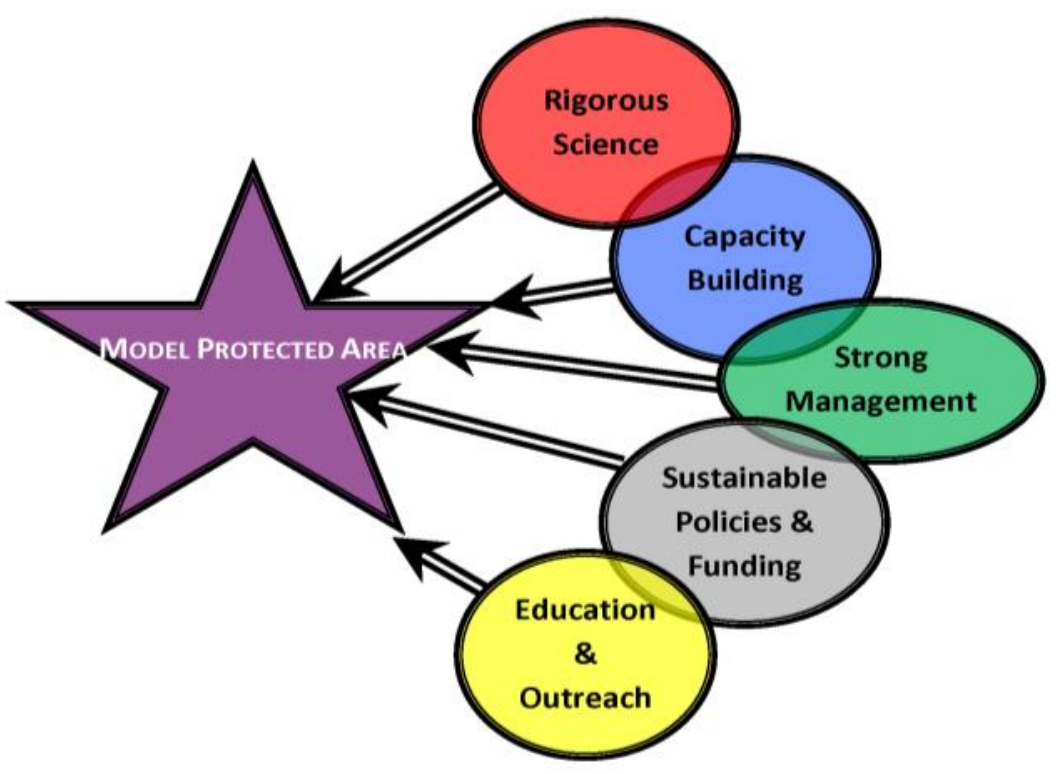

Figure 2. Five intersecting components to the development of a model protected area an arid, continental climate characterized by relatively wet, hot summers (to $43^{\circ} \mathrm{C}$ ), cold winters (to $-40^{\circ} \mathrm{C}$ ), and dry and windy springs with extremely low humidity. Most of the limited precipitation $(\sim 60 \mathrm{~cm} / \mathrm{yr})$ falls in summer as rain (Reading et al., 2011).

Ikh Nart, like other nature reserves in Mongolia, is a multi-use landscape. Approximately 110 families live as transhumant pastoralists in and around the immediate vicinity of the reserve, raising livestock (mostly sheep, goats and horses) (Reading et al., 2011; Davie et al., 2014a). These families move about 5 to $>50 \mathrm{~km}$ between winter and summer ger (or yurt) sites. A network of 2track dirt roads connects ger sites and some lead to aimag and soum governance centres (Davie et al., 2014a). Humans have inhabited the region for millennia and numerous archaeological sites occur in the landscape (Tserendagva et al., 2014, 2015; Schneider et al. In press). Intensive livestock grazing represents a conservation threat, especially given the dry and fragile nature of the ecosystem (Reading et al., 2010c, 2015). Mining represents another threat (Reading et al., 2015). Seams of amethyst quartz and fluorite run through the reserve and have been illegally exploited by local miners and larger commercial operations. The reserve is also surrounded by dozens of mining concessions.

\section{DEVELOPING A MODEL PROTECTED AREA}

Effectively managing protected areas for biodiversity conservation requires several components. Five main aspects characterize our work, overlapping and complementing each other. These components include 1) conducting rigorous scientific research to obtain reliable data upon which to base management; 2) developing better management; 3) building local capacity; 4) conservation education and outreach activities, including livelihood enhancement; and 5) creating sustainable administrative policies and funding mechanisms (Figure 2).

\section{Gathering a foundation of scientific data}

Effective biodiversity conservation requires understanding the biological and social context, including the flora, fauna, ecology, local culture, politics and socio-economics. The first step towards transforming Ikh Nart, involved acquiring scientific knowledge. Little information existed about the reserve, and several studies gathered data for use in managing the region. This information included descriptive data (e.g., habitat types, species richness, abundance and distribution), more complex ecological studies, predictive models and experimental results. A research station gradually developed from a single ger that eventually expanded to include multiple gers, outbuildings, specialized equipment and sustainable energy (solar) that can accommodate about 40 people.

Ecological research initially focused on key species and over time expanded to include other species. As Ikh Nart was originally established specifically to conserve argali sheep (Reading et al., 2011), the first research project, beginning in 2000, focused on this species (Reading et al., 2003, 2005a, 2009; Tserenbataa et al., 2004; Kenny et al., 2008; Singh et al., 2010a; Young et al., 2011; Amgalanbaatar et al., 2014). Argali function as a flagship species for our work. Other research projects soon followed. Studies of Siberian ibex (Capra sibirica; Reading et al., 2007; Singh et al., 2010b; Wingard et al., 2011a) led to exploring potential competition between argali, ibex and livestock (Wingard et al., 2011b). This mountain ungulate research resulted in annual monitoring of vegetation in the reserve (Mandakh et al., 2005). 


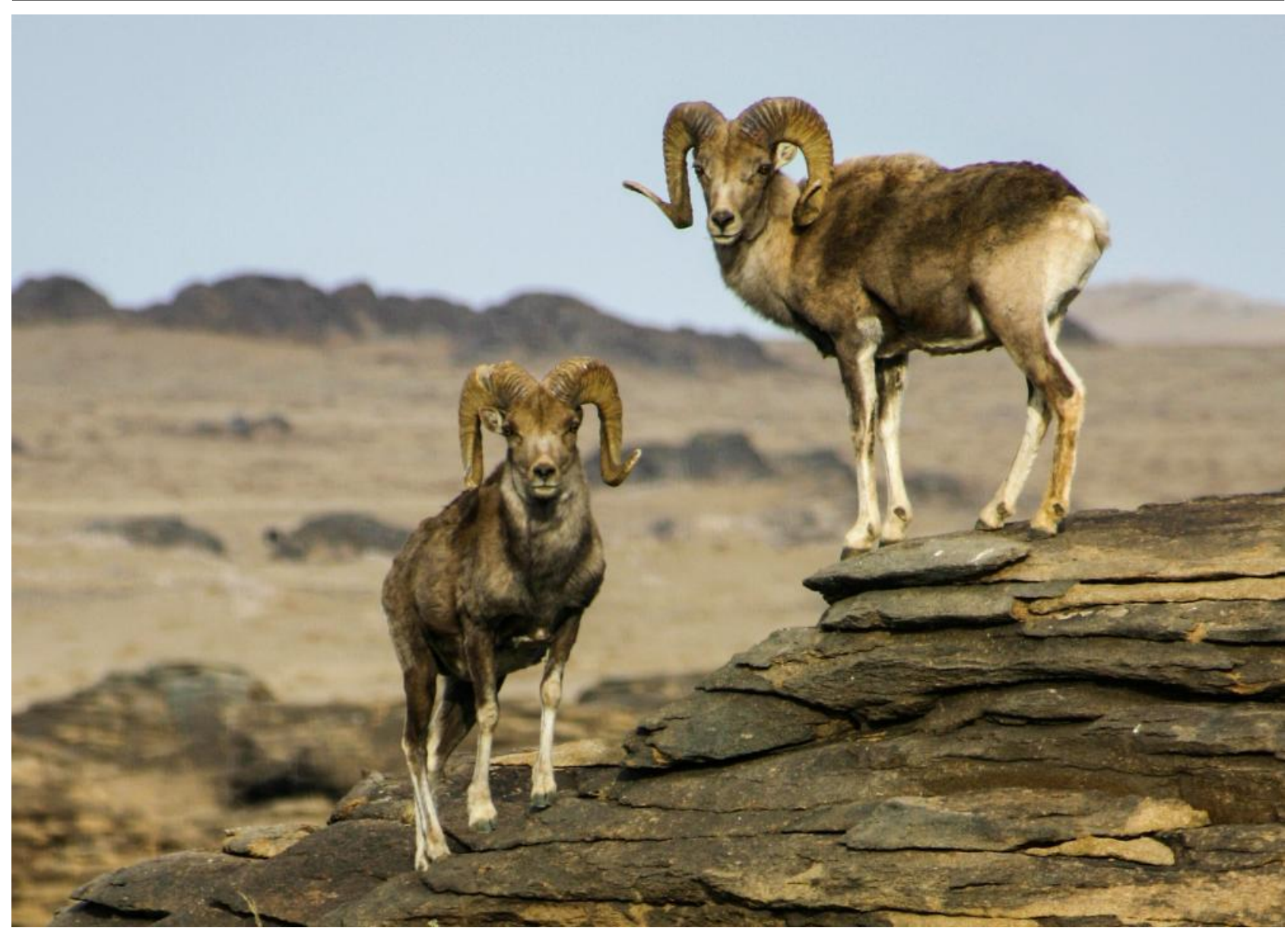

Argali (Ovis ammon) rams, Ikh Nart Nature Reserve, Mongolia @ Richard Reading

Large numbers of breeding raptors are attracted to Ikh Nart because of its trees and rocky outcrops, particularly Cinereous Vultures (Aegypius monachus) and Lesser Kestrels (Falco naumanni), both species of conservation concern (Gombobaatar \& Monks, 2011). Some of us, therefore, began more in-depth research into the nesting ecology, movement and migration patterns of these species (Reading et al., 2005b, 2010a; Batbayar et al., 2008; Kenny et al., 2013, 2015), as well as gathered data on other breeding raptors.

In the mid-200os, research expanded further to include meso-carnivores and their prey that focused primarily on the ecology of red (Vulpes vulpes) and corsac foxes ( $V$. corsac; Murdoch et al., 2010a, 2010b, 2016; Lkhagvasuren et al., 2016), but also gathered data on Pallas' cats (Otocolobus manul) and Asian badgers (Meles leucurus) (Murdoch et al., 2006a; Murdoch \& Buyandelger, 2010). The meso-carnivore project also initiated annual monitoring of small mammal and lizard populations (Murdoch et al., 2010c, 2010c). The project further led to research on resource partitioning by two species of hedgehogs (Murdoch et al., 2006b; Reading et al., 2010b; Zapletal et al., 2012, 2015), the role of Siberian marmots (Marmota sibirica) as a keystone species (Murdoch et al., 2009, 2013), insect fauna, wolf
(Canis lupus) ecology and conservation (Davie et al., 2014a, 2014b), and ecological impacts of landscape change (Lkhagvasuren et al., 2016). Herpetological work expanded from population surveys to ecological and disease studies. Finally, the most recent research project focuses on bats (Davie et al., 2012).

The social and cultural context of Ikh Nart was assessed informally and formally. More formal social science research included a major archaeological project (Tserendagva et al., 2014, 2015; Schneider et al., In press), studies focused on local people's values and attitudes towards Ikh Nart, its species and conservation (Davie et al., 2014a; Sarmento \& Reading 2016), and work to assess the effectiveness of our education and outreach programmes (see below). Informally, the project team evaluated the structures of local communities; power and authority relationships between key stakeholders and different levels of government (bag1, soum, aimag and national); and the distribution of resources, including wealth, knowledge and expertise.

This broad range of research topics helped us better understand much of the ecological and social context. In turn, data from the research helped inform science-based management. The wide range of research targets also enabled the training of students from several disciplines. 


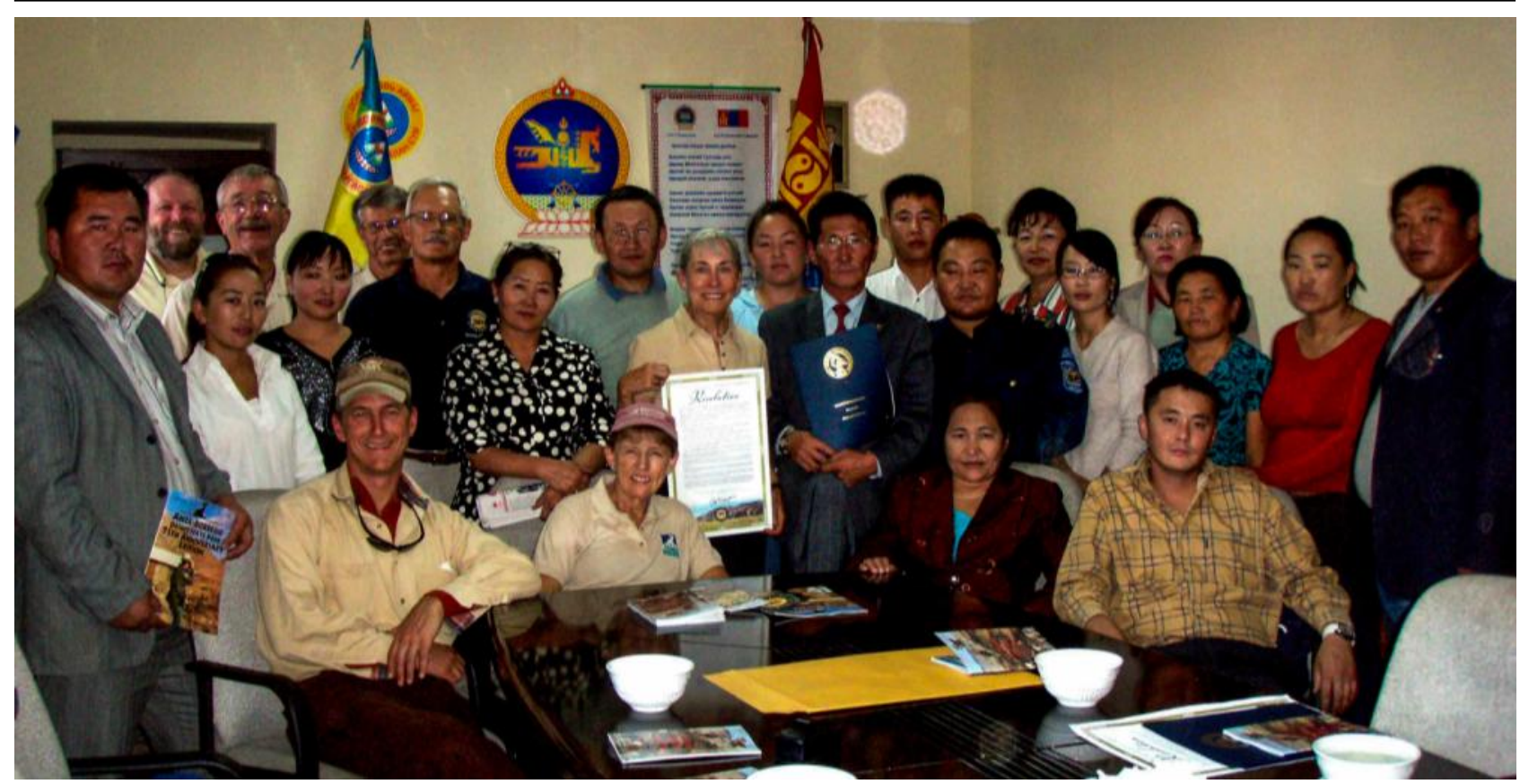

Signing of the sister park agreement between Ikh Nart Nature Reserve, Mongolia and Anza-Borrego Desert State Park, California, USA @ Richard Reading

\section{Active conservation management}

Shortly after initiating the argali research, project team leaders worked with the local Dalanjargalan Soum Administration to hire a local pastoralist as a ranger for Ikh Nart, tasked mainly with reducing wildlife poaching. The ranger arrested two poachers within the first few months and additional poachers and illegal miners in subsequent years at a decreasing rate; successfully reducing illegal activities in Ikh Nart. Over time, the ranger programme grew to include six full time rangers, with expanded roles like ecosystem monitoring and building community relationships.

In the mid-200os, management planning began (Figure 1). Workshops and study tours of better managed parks in Mongolia helped inform Ikh Nart administration staff. The workshops resulted in Ikh Nart's first five-year management plan (2007 - 2012) that specified objectives, goals, actions and activities, and outlined a formal structure for authority. The plan also included a process for decision-making and steps to monitor and adapt management over time. Simultaneously, the first author solicited the support of Anza-Borrego Desert State Park in southern California. The largest state-managed protected area in the contiguous United States, AnzaBorrego was a good match for Ikh Nart because it is also run by a local (state) government, protects a similar desert ecosystem with an endangered population of desert bighorn sheep (Ovis canadensis) (like argali), and includes numerous cultural sites. The state park, along with the Anza-Borrego Foundation (ABF; established to support the state park), became actively involved in Ikh Nart management by providing funds, training, equipment, and expertise in law enforcement and regulation. In 2008, the California State Park Commission formerly recognized a sister park relationship between Ikh Nart and Anza-Borrego. ${ }^{2}$

Ikh Nart's relationship with Anza-Borrego yielded significant benefits immediately. California State Park staff visited Ikh Nart each year to assist with training, management plan implementation and park infrastructure development, such as creating and erecting boundary and entrance signs. Rangers received uniforms, equipment and training in law enforcement, first aid, data collection and guest relations. This helped improve the knowledge, skills and capacities of rangers and built a sense of professionalism and pride around the importance of protecting Ikh Nart. ABF provided funding for motorcycles and a ranger salary. Several Mongolian partners visited Anza-Borrego as well. Finally, archaeology experts joined the team to document, study, conserve and protect the large number and breadth of cultural sites that span from the Neolithic to the Buddhist purges of the 1930 .

In 2012, the UNDP initiated planning for a GEFsupported SPAN project. Their assessment of most of Mongolia's protected areas ranked Ikh Nart at the top and its inclusion in the project as one of two model protected areas. SPAN support provided funding to develop Ikh Nart's second five-year management plan (2013 - 2017), which led to establishing 1) a reserve administration, 2) an Ikh Nart management team, comprised of local government officials, local nomadic pastoralists and protected area staff, and 3) an Ikh Nart 
advisory team, comprised of international experts. Discussions at the national and local governmental levels resulted in awarding management of the reserve to the Argali Wildlife Research Center (AWRC); the first time a non-governmental organization acquired the authority to manage a nature reserve in Mongolia. Established over a decade earlier, AWRC had established itself as a small, but relatively strong, science-based non-profit organization. In addition to developing sustainable funding for Ikh Nart (see below), AWRC continues to improve management. Dornogobi Aimag donated funding to construct a park headquarters and provide modest financial support for three staff salaries. The SPAN project provided support to purchase office equipment and supplies, additional motorcycles for rangers, and a vehicle for the park administration.

\section{Capacity development}

All of the work at Ikh Nart was based on the premise that local people, provisioned with knowledge, skills, salaries and equipment, will far surpass foreign experts in their ability to devise and implement successful conservation solutions. As such, all team members collaborated closely and engaged in reciprocal capacity building in every aspect of our work. Everyone involved benefitted greatly from these relationships.

Since 2001, dozens of undergraduate and graduate students from Mongolia (primarily), the U.S., China, Sweden, Russia and the United Kingdom have trained in Ikh Nart. Students have gone on to assume positions with universities, elementary and secondary schools, government agencies, non-governmental organizations (NGOs), and the Mongolian Academy of Sciences. Many former students now mentor their own students, some of whom study in Ikh Nart, developing a legacy of conservationists that will hopefully continue.

In addition to students, capacity development proceeded both formally, through workshops and training courses, and informally, by working together closely in the field, with conservation professionals to provide state-of-theart knowledge in theories and techniques. For example, American and Mongolian experts provided a series of formal training courses for local rangers. These experts also accompanied rangers in the field to assist in patrols and provide guidance and best management practices. Other Ikh Nart professionals received similar training, including social and ecological research methods, park management, wildlife veterinary medicine, archaeology, and education and outreach programming. Today, AWRC, an NGO our project helped create and train, manages Ikh Nart. Project staff also assisted the SPAN project team.

\section{Community education and outreach}

Local communities can make or break conservation efforts. People create conservation problems and thus must help to develop effective, long-term solutions (Dudley et al., 2014). Education and outreach work included programmes to supplement in-school education, building local capacity, engaging communities in conservation, promoting positive attitudes towards wildlife, and empowering local students to become conservation leaders. This work looked to connect and empower local people in conservation through environmental exploration, providing hands-on experience, and promoting positive attitudes and behaviours towards wildlife. A backwards design process and logic model helped determine appropriate programmes (McLaughlin \& Jordan, 2004), leading to three key programmes: 1) conservation clubs, 2) conservation exchange programme, and 3) community engagement. Examples of the work included teacher trainings for conservation education; developing educational materials for teachers, such as Nomadic Nature Trunks; and, a school exchange programme for schools near Ikh Nart and Denver, Colorado, USA.

Creating conservation clubs helped increase knowledge of environmental issues and develop experiences through focused participation (Rickinson, 2001; Jacobson et al. 2006). Service learning, a teaching and learning strategy that integrates meaningful community service with instruction and reflection to enrich the learning experience, teach civic responsibility, and strengthen communities, formed a critical component. Conservation club members designed and implemented projects that engaged school groups and community members, encouraging them to take conservation action (Morgan \& Streb, 2001). Through an exchange programme, students and teachers travelled between Denver and Mongolia. Participants engaged in wildlife research in both countries to help build skills, knowledge and significant life experiences (Tanner, 1980; Gmelch, 1997).

In 2010, some of the authors helped establish Nomadic Nature Conservation (NNC), a Mongolian non-profit organization dedicated to conservation education through a Nomadic Nature Trunk programme. Nomadic Nature Trunks provide culturally appropriate natural science and conservation education materials and curricula to rural communities throughout Mongolia in a design that encourages creative learning and total community engagement.

Lastly, outreach methods included our annual Community Day. School exchange students participated in and helped implement a fun day that included 
educational games, presentations by Mongolian graduate students, contests (e.g., poetry, art), and a traditional Mongolian-style barbecue. Participants left with a greater understanding of our work, the importance of conserving nature, and how Ikh Nart benefits them and wildlife.

At higher education levels, training programmes focused on undergraduate and graduate students, as well as researchers from the Mongolian Academy of Sciences. Training included mentoring students in the field and providing courses in research methods, statistics and other forms of data analysis, proposal writing and drafting scientific manuscripts. Some of us also served on university committees. Thus far, research at Ikh Nart has resulted in 125 peer-reviewed papers and book chapters. More importantly, former students have assumed positions in academia, government, and other non-profit organizations and now contribute to conservation in Mongolia

Enhancing local livelihoods helps build support from people and communities living in and near protected areas (Dudley et al., 2014). Although the project provided only modest financial benefits to local people, its actions helped increase local support (Sarmento \& Reading, 2016). More formal management of Ikh Nart led to job openings for local people, including positions as rangers and other protected area staff, work in the research station, and part-time work assisting with conservation and research activities. For example, every year, researchers hired over a dozen pastoralists on horseback and motorcycles to help capture argali sheep and ibex for radio-collaring. The project purchased supplies from local people (such as goats for meat) and helped start a new and improve an existing, locally-managed tourism camp, respectively. These camps provided additional employment and income generating opportunities.

The project helped form a women's cooperative that creates small handicrafts (e.g., carvings and felt products) for sale to tourists and in the U.S. A modest microloan allowed women to purchase a felt press, handtools, supplies and marketing, including brochures. Investing in women makes good conservation policy. Women typically have little opportunity to earn cash in developing world economies, yet they form the backbone of the family unit. In our experience, while men often focus on the short-term (i.e., feeding their families tomorrow), women tend to focus more on the long-term (i.e., a healthy, sustainable environment for their children and grandchildren), and empowering women helps them make better reproductive decisions. Named "Ikh Nart is Our Future", these women realized the link between their new enterprise and successful conservation of the reserve.
Arguably more important, local people have begun to understand how protecting Ikh Nart helps them by providing things like a better and more consistent water supply, improved forage, a healthier environment for their families, and the joy of being able to observe wildlife (Sarmento \& Reading, 2016). For example, some pastoralists initially opposed our efforts to protect the heads of springs in the reserve, as they believed it reduced access to water for their livestock, but today they understand how our efforts helped maintain a more consistent supply of water, benefitting both wildlife and livestock.

\section{Creating sustainable policies and funding mechanisms}

Following years of working with the local soums and national-level Protected Areas Bureau, some of the authors developed a new model for managing nature reserves that relied on a non-governmental organization (NGO). In Mongolia local governments lack the capacity or expertise to effectively manage protected areas, so involving a Mongolian NGO made sense. That NGO, AWRC, worked effectively with the two soum and one aimag governments responsible for Ikh Nart, resulting in significant conservation advances. AWRC also worked with us to develop creative mechanisms for developing sustainable income.

Strong ecological and social underpinnings helped AWRC realize tangible changes. For example, soum governments created local protected areas covering 55,621 ha that nearly surround Ikh Nart. At the time of writing, AWRC and a third soum, Bayanjargalan, were planning an additional 34,175 ha local protected area. These local protected areas create a buffer zone around Ikh Nart and AWRC hopes to eventually merge them with Ikh Nart proper at the national level. The authors believe that the trust we have developed with the local governments and communities and our admittedly modest livelihood enhancement projects combined with ecological information and Mongolia's culture of respect for nature helped make these protected areas possible.

Sustainable conservation of Ikh Nart also required working to change government laws, regulations and policies to benefit protected areas management throughout Mongolia. For example, under Mongolian law, protected areas rangers cannot carry firearms and lack the authority to arrest people; they can only issue ticket citations. Instead, unarmed rangers must approach armed men and travel to the nearest community - often dozens of kilometres away - to find a police officer to make the actual arrests. Poachers have killed rangers in other protected areas in Mongolia. To us, such laws 


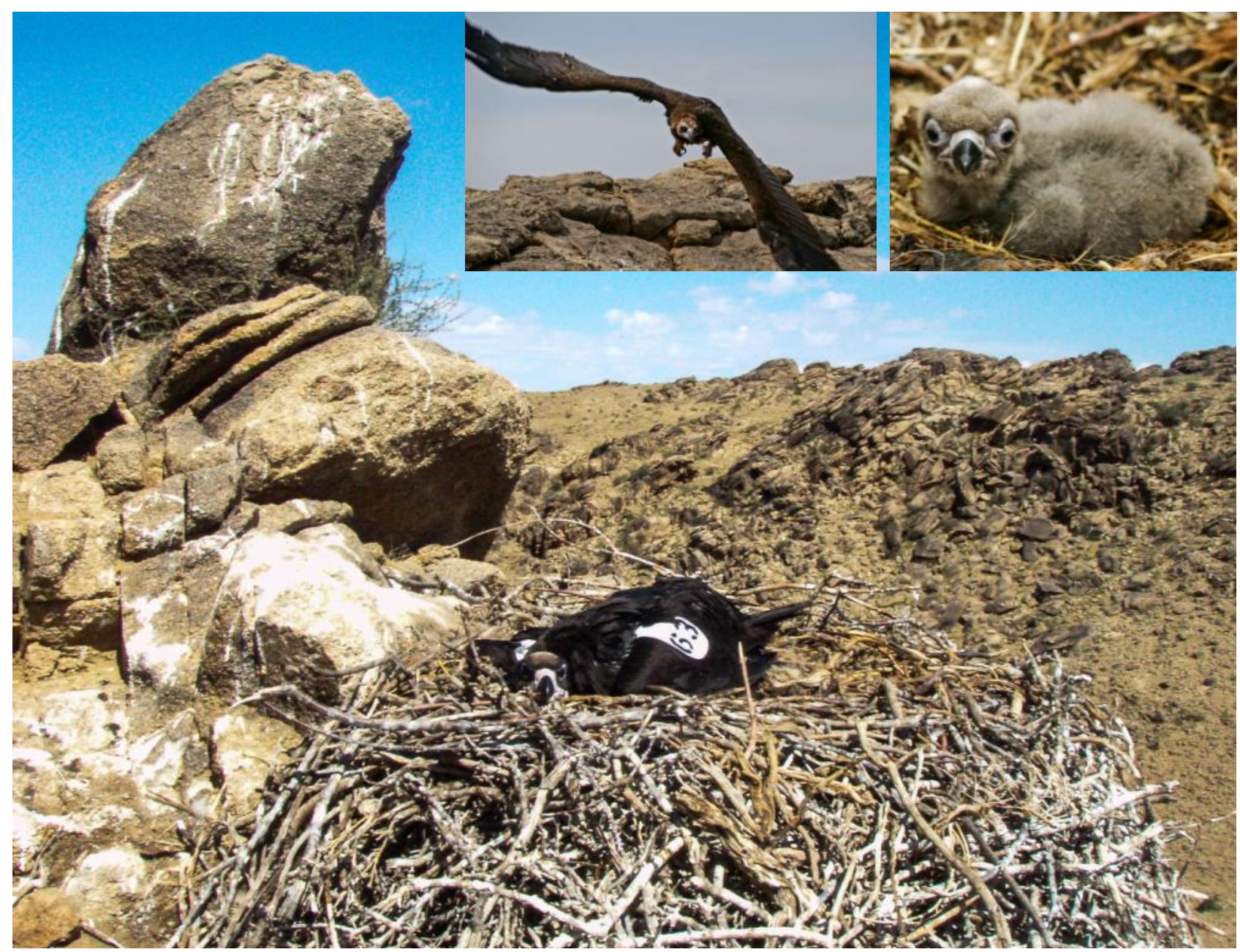

Cinereous Vultures (Aegypius monachus): Clockwise from bottom: Wing tagged fledgling, adult flying, and young chick (C) Richard Reading

needlessly endanger rangers and impede law enforcement, so we continue working to change this and other laws that the authors believe would improve protected area management.

Managing livestock grazing within Ikh Nart would likely also improve sustainable conservation. Mongolian law permits pastoralists to graze livestock in nature reserves (Wingard \& Odgerel, 2001). Yet, huge increases in livestock numbers threaten conservation (Reading et al., 2010c, 2015). Already, Ikh Nart limits livestock grazing within its Core Zone, the boundaries of which we created with local input. Additional work with local pastoralists will focus on placing limits on livestock numbers throughout the rest of the reserve, but will likely prove controversial.

Perhaps most importantly, the project continues working to develop long-term, sustainable funding. AWRC helped establish entrance fees for people, vehicles and cameras as called for under the Mongolian protected area law (Wingard \& Odgerel, 2001). Closely related to entrance fees, the Ikh Nart administration also charges a bed tax for visitors staying at Ikh Nart's two tourism facilities and an exclusivity fee for a high-end camp catering to foreign tourists.

Perhaps the greatest potential source of income comes from a new law that requires mining companies to pay offset fees of $\$ 50 / \mathrm{ha} / \mathrm{yr}$ for land they disturb. These offset fees must go towards environmental mitigation, including protected areas management. With much of Mongolia leased or available for lease for mining or exploration (Reading et al., 2015), these fees represent a potentially significant source of income. AWRC is currently working with Dornogobi Aimag (responsible for imposing these fees within its own province) and several mining companies to draft long-term contracts to support Ikh Nart.

In 2015, the Ikh Nart administration created a trust fund to help provide support. Yet, donations to the fund remain difficult to obtain. Other modest sources of income include a small fee imposed on Ikh Nart's research station; a proposal to impose crossing fees on mining trucks that traverse the reserve; and sales of merchandise to tourists, including t-shirts, hats and guidebooks. 


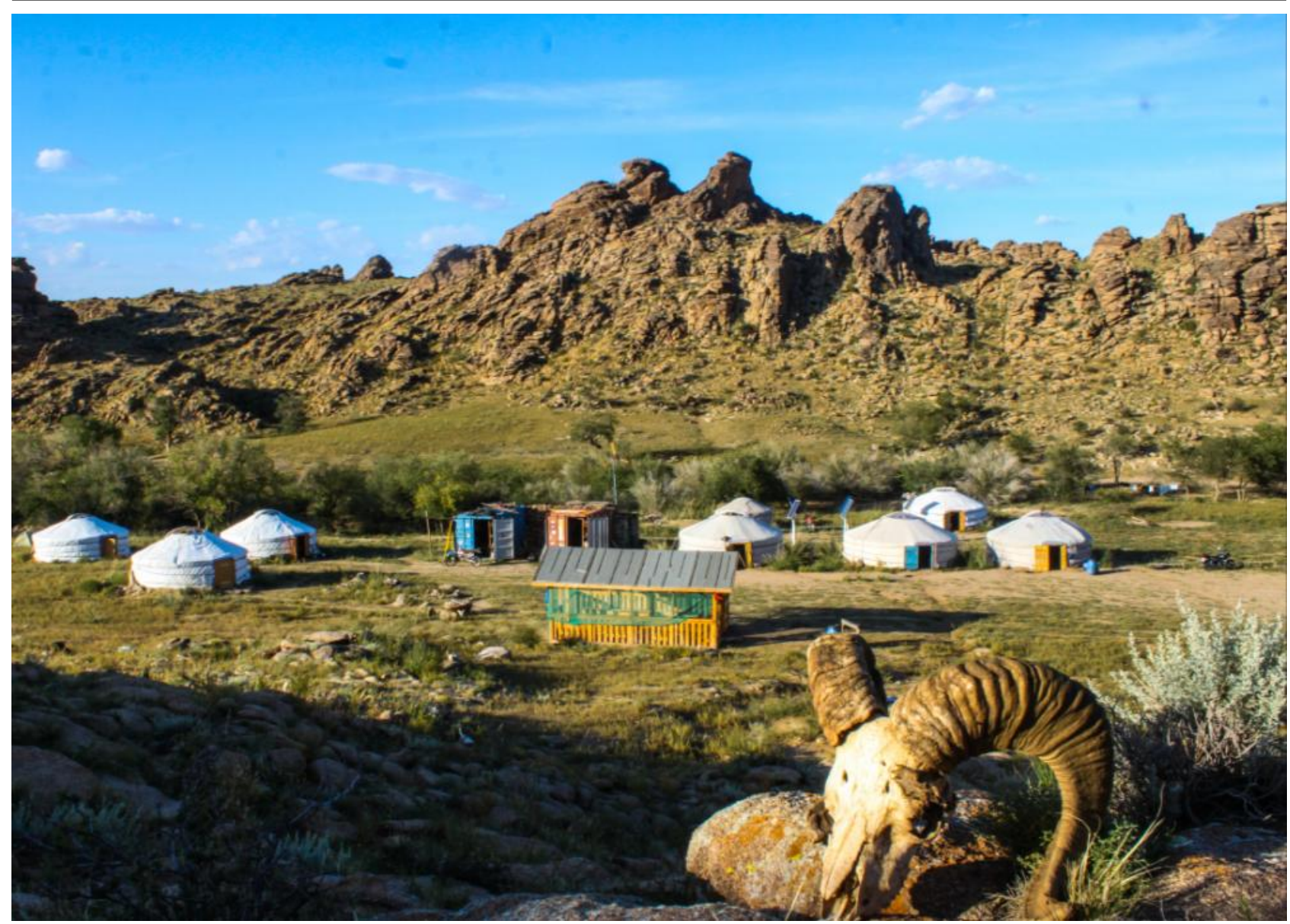

Research Station in Ikh Nart Nature Reserve, Mongolia @ Richard Reading

\section{DISCUSSION}

In 2012, the UNDP's SPAN project named Ikh Nart a Model Protected Area, a goal the project had long sought. However, from our perspective, Ikh Nart is just now reaching the level of effectiveness the authors hope to achieve. Expanding and diversifying its income base should help. In addition to recognition by UNDP, the project has received awards from several organizations, including the local soums, Dornogobi Aimag, the Mongolian Academy of Sciences, Mongolian Ministries for Environment and Green Development and Science and Education, the Mongolian National Education University, the US Embassy in Mongolia, and the Association of Zoos and Aquariums.

While awards are positive and appreciated, true measures of success lie in biological and social indicators. Although argali and ibex population estimates include large confidence intervals, these populations have increased by an estimated 200-300 per cent (Wingard et al., 2011a, unpubl. data). Ikh Nart has become a "source" population for argali, resulting in dispersal and re-establishment of small populations nearby (unpubl. data). Cinereous Vultures fledgling numbers have increased by about 35 per cent (unpubl. data). Equally, or perhaps more, importantly, local people who once did not know that Ikh Nart was protected increasingly support the reserve (Sarmento \& Reading, 2016). Local people now organize periodic litter clean-up days. Perhaps more telling, a local pastoralist requested the project's assistance in writing a proposal to restore damage from decades' old mining exploration sites. Some of the authors helped. The local pastoralist received the grant and local people began restoration. Several governmental and non-governmental organizations have requested our assistance to replicate the Ikh Nart model in other Mongolian protected areas, representing another measure of success. In response, some of the authors have begun working in Toson Hulstai Nature Reserve and Suikhent National Monument to adapt the Ikh Nart model to those protected areas.

All protected areas are unique, but the authors believe that the Ikh Nart approach offers a useful model that managers can adapt to their circumstances. Specifically, combining rigorous research, active conservation management, capacity development, community education and outreach with a livelihood enhancement component, and sustainable financing and policies promises to improve how any protected area functions. In addition, our experiences at Ikh Nart offer valuable lessons to other protected areas. 
The long-term and consistent presence of researchers has resulted in wildlife populations habituated to people. This provides eco-tourism opportunities not found in most of Mongolia. For example, argali sheep exhibit flight distances (the distance at which they will run from people; a measure of fear) of three to five kilometres. Today, in Ikh Nart, argali flight distances have dropped to $<100 \mathrm{~m}$ in some areas. The vast majority of tourism in Mongolia focuses on culture and stunning landscapes. Many tour operators believe that wildlife-based trips can extend stays. Yet, tourism requires careful management to ensure that it does not negatively impact the wildlife, scenery and local culture tourists hope to experience. The authors believe that responsible tourism focused on manageable numbers can accomplish this goal and envision both low numbers of relatively high-end (i.e., expensive), mostly international tourists at the more exclusive, privately run camp and larger numbers of lower-end tourists at the aimag operated tourist camp that caters primarily to Mongolian tourists.

A number of challenges faced the Ikh Nart project. Conducting research in remote locations proved challenging, especially prior to establishing the research station. Garnering sufficient funding for research in a temperate (as opposed to a tropical) location continues to be a challenge. Attracting sufficient tourists has proven elusive, but better advertising and publicity will hopefully help address this deficit.

The authors learned several lessons that may help other protected areas. First, strong, collaborative partnerships are essential. Success in Mongolia required incorporating diverse perspectives, so some of us established a core group of key stakeholders from academic institutions, non-profit organizations, government agencies and the local community. That partnership has persisted and expanded as the work grew and evolved. The inclusive atmosphere fostered new, diverse and creative perspectives on how best to manage and conserve the region.

Second, the initial focus on flagship and umbrella species (e.g., argali sheep, Cinereous Vultures) proved effective. Centring work on these species helped generate support among local herders, communities, politicians and decision-makers. Although the use of surrogate species has resulted in mixed success elsewhere (Caro \& O’Doherty, 1999; Andelman \& Fagan, 2000), at Ikh Nart promoting flagship species led to increased commitment. Wildlife plays an important role in traditional Mongolian culture, with reverence for animals and nature remaining important, especially among rural communities (Reading et al., 2010, 2015).
Third, the sister-park agreement between Ikh Nart and Anza-Borrego Desert State Park brought new, positive dimensions to the project and quickly strengthened management. Anza-Borrego and ABF provided management approaches and perspectives, training, funding and international exposure to Ikh Nart. The strong, on-going sister-park relationship provides a sense of 'global' connection and pride to the local community.

Finally, the authors attribute much of our success to our partners' long-term commitment. Conservation success rarely occurs rapidly. It took approximately 10 years to move Ikh Nart from 'paper park' to functioning reserve, despite various challenges, such as periods of lean funding and government turn-over. Over 16 years later, that commitment to Ikh Nart continues. Long-term data provide new insights and new management approaches.

Looking ahead, the authors envision Ikh Nart entering a new phase of management focused on fundraising and developing tools to help inform decision-making. Ikh Nart faces increasingly complex management challenges (e.g., mitigating climate change impacts) that require efficacious decisions resulting in maximum benefits to the biological and cultural resources of the reserve in ways that ensure enduring support from the local community.

\section{ENDNOTES}

${ }^{1}$ A bag is a formal community of herders below the soum level; a soum is similar to a county; and an aimag is a state or province.

${ }^{2}$ http://www.parks.ca.gov/pages/712/files/

Ano_Mongolia_Sisterpark_ResolutionMay2008.pdf and http://www.ikhnart.com/

AB_IN_Sister_Park_Governors_Communication_2008. pdf viewed 11.29.2015

\section{ACKNOWLEDGEMENTS}

Many people, too numerous to cite, helped make this work possible. We especially thank our Mongolian students and colleagues, and all of our Earthwatch volunteers. The Denver Zoological Foundation, Earthwatch Institute, Trust for Mutual Understanding, Mongolian Conservation Coalition, Mongolian Academy of Sciences, Anza-Borrego Foundation, AZA Conservation Endowment Fund, Disney Conservation Fund, Mongolian National University, Mongolian State University of Education, Noah's Ark Foundation, Rufford Foundation, Fulbright Scholar Program, University of Vermont, SPAN project UNDP and many private donors provided support. 


\section{ABOUT THE AUTHORS}

Richard P. Reading is Director of Research \& Conservation at Butterfly Pavilion and an adjunct professor and scholar in residence at the University of Denver.

James D. Murdoch is an Associate Professor and Chair of the Wildlife and Fisheries Biology Program at the University of Vermont.

Sukh Amgalanbaatar is the Executive Director of the Argali Wildlife Research Center and Director of Ikh Nart Nature Reserve.

Hannah Davie is a Ph.D. student from Nottingham Trent University in the UK.

Mark Jorgensen spent 36 years working for California State Parks in the Anza-Borrego Desert State Park, finishing his career as the superintendent of the park.

David Kenny is a consulting wildlife veterinarian with experience of working in Mongolia since 2000.

Tserendorj Munkhzul is a wildlife biologist within the Mammalian Ecology Laboratory of the Mongolian Academy of Sciences.

Ganbold Onloragcha is a Ph.D. student at the Department of Animal Science of Chungnam National University, Daejon, South Korea.

Lynn Rhodes is the retired Chief of California State Parks' Law Enforcement Division, a consultant, and Trustee of the Anza-Borrego Foundation.

Joan Schneider, lead scientist for the Ikh Nart archaeology project, was Associate State Archaeologist of California State Parks (now retired).

Tuvendorj Selenge is Executive director of the Mongolian Conservation Coalition.

Erin Stotz is Community Conservation Manager at Denver Zoological Foundation.

Suuri Buyandelger is a Ph.D. student in the Biology Department at the National University of Mongolia.

Ganchimeg Wingard is Mongolia Program Director at Denver Zoological Foundation.

\section{REFERENCES}

Amgalanbaatar, S., Dorzhiev, Ts.Z. and Reading, R.P. (2014). 'Structure of argali sheep Ovis ammon habitat in Mongolia and its dynamics in the initial period of the 21st century'. Vyestnik Biologia, Gegrafia 4(1):58-66. (In Russian)

Andelman, S.J. and Fagan, W.F. (2000). Umbrellas and flagships: efficient conservation surrogates or expensive mistakes. Proceedings of the National Academy of Sciences 97:5954-5959. DOI:10.1073/pnas.100126797

Batbayar, N., Reading, R.P., Natsagdorj, T. and Kee, P.W. (2008). 'Movement patterns of cinereous vultures in Mongolia'. Falco 32:5-7.

Bruner, A. G., Gullison, R. E., Rice, R.E. and da Fonseca, G.A.B. (2001). Effectiveness of parks in protecting tropical biodiversity. Science 291:125-128. DOI:10.1126/ science.291.5501.125

Caro, T.M. and O'Doherty, G. (1999). On the use of surrogate species in conservation biology. Conservation Biology 13:805-814. DOI: 10.1046/j.1523-1739.1999.98338.x

Davie, H., Murdoch, J., Erdene Naran, N., Ariunbold, J., Batdorj, S. and Reading, R. (2012). 'Bat diversity at Ikh Nart Nature Reserve, Mongolia'. Mongolian Journal of Biological Sciences 10:33-40.

Davie, H., Stokowski, P., Ankhbayar, L. and Murdoch J. (2014a). 'Herders and wolves in post-Soviet society: an ethnographic study in Mongolia's Ikh Nart Nature Reserve'. Human Dimensions of Wildlife 19:319-333. dx.doi.org/10.1080/10871209.2014.915599

Davie, H., Murdoch, J., Ankbayar, L. and Reading, R.P. (2014b). 'Measuring and mapping the influence of landscape factors on livestock predation by wolves in Mongolia'. Journal of Arid Environments 103:85-91. dx.doi.org/10.1016/j.jaridenv.2014.01.008

Dudley, N., Groves, C., Redford, K.H. and Stolton, S. (2014). 'Where now for protected areas?' Setting the stage for the 2014 World Parks Congress. Oryx 48(4):496-503. dx.doi.org/10.1017/S0030605314000519

Gmelch, G. (1997). 'Crossing cultures: Student travel and personal development'. International Journal of Intercultural Relations 21(4):475-490. dx.doi.org/10.1016/ S0147-1767(97)00021-7

Gombobaatar, S. and Monks, E.M., (eds.). (2011). Mongolian Red List of Birds. Regional Red List Series Vol. 7. London \& Ulaanbaatar: Zoological Society of London, National University of Mongolia \& Mongolian Ornithological Society.

Jackson, D., Murdoch, J. and Mandakh, B. (2006). 'Habitat classification using Landsat-7ETM+ imagery of the lkh Nart Nature Reserve and surrounding areas in Dornogobi and Dundgobi Aimags, Mongolia'. Mongolian Journal of Biological Sciences 4:33-40.

Jacobson, S. K., McDuff, M.D. and Monroe, M.S. (2006). Conservation education and outreach techniques. New York: Oxford University Press.

Kellett, M. J. (2015). 'America needs more national parks'. In: G. Wuerthner, E. Crist, and T. Butler (eds.) Protecting the wild: Parks and wilderness, the foundation for conservation, pp. 194-207. Washington, D.C.: Island Press.

Kenny, D. E., DeNicola, A.J., Amgalanbaatar, S., Namshir, Z., Wingard, G., Tuya, T. and Reading, R.P. (2008). 'Three field capture techniques for free-ranging argali sheep (Ovis ammon) in Mongolia.' Zoo Biology 27:137-144. dx.doi.org/10.1002/zoo.20168

Kenny, D. E., Bickel, C.L. and Reading, R.P. (2013). 'Veterinary assessment for free-ranging Eurasian Black Vulture 
(Aegypius monachus) chicks in southeastern Mongolia'. Topics in Companion Animal Medicine 28(4):143-150. dx.doi.org/10.1053/j.tcam.2013.09.002

Kenny, D., Kim, Y.J., Lee, H. and Reading, R.P. (2015). 'Blood lead levels for Eurasian Black Vultures (Aegypius monachus) migrating between Mongolia and the Republic of Korea'. Journal of Asian-Pacific Biodiversity 8(3):199202. dx.doi.org/10.1016/j.japb.2015.08.004

Lkhagvasuren, M., Murdoch, J., Munkhzul, T. and Strong, A. (2016). 'Predicting the effects of habitat loss on corsac foxes in Mongolia'. Journal of Mammalogy 97(4):11531163. DOI:10.1093/jmammal/gyw067

Mandakh, B., Wingard, G. and Reading, R.P. (2005). 'Winter pasture conditions and forage use by argali (Ovis ammon) in Gobi Gurvan Saykhan National Park'. Erforschung Biologischer Ressourcen der Mongolei (Halle/Saale) 9:71-76.

McLaughlin, J. A. and Jordan, G.B. (2004). 'Using logic models'. Handbook of Practical Program Evaluation 2:7-32.

Morgan, W. and Streb, M. (2001). 'Building citizenship: how student voice in service-learning develops civic values'. Social Science Quarterly 82(1):154-169. dx.doi.org/10.1111/0038-4941.00014

Murdoch, J. and Buyandelger, S. (2010). 'An account of badger diet in an arid steppe region of Mongolia'. Journal of Arid Environments 74:1348-1350. dx.doi.org/10.1016/ j.jaridenv.2010.04.009

Murdoch, J., Munkhzul, T. and Reading, R. (2006a). 'Pallas' cat (Otocolobus manul) ecology and conservation in the semidesert steppes of Mongolia'. Cat News 45:18-19.

Murdoch, J., Batdorj, S., Buyandelger, S., Kenny, D. and Reading, R. (2006b). 'Ecology of the Daurian hedgehog (Hemiechinus dauuricus) in Ikh Nart Nature Reserve, Mongolia: Preliminary findings'. Mongolian Journal of Biological Sciences 4(2):25-32.

Murdoch, J., Munkhzul, T., Buyandelger, S., Reading, R. and Sillero-Zubiri, C. (2009). 'The Siberian marmot as a keystone species? Observations and implications of burrow use by corsac and red foxes in Mongolia'. Oryx 43:431-434. dx.doi.org/10.1017/S0030605309001100

Murdoch, J., Munkhzul, T., Buyandelger, S. and Sillero-Zubiri, C. (2010a). 'Survival and cause-specific mortality of corsac and red foxes in Mongolia'. Journal of Wildlife Management 74:59-64. dx.doi.org/10.2193/2009-059

Murdoch, J., Munkhzul, T., Buyandelger, S., Reading, R. and Sillero-Zubiri, C. (2010b). 'Seasonal food habits of corsac and red foxes in Mongolia and the potential for competition'. Mammalian Biology 75:36-44. dx.doi.org/10.1016/j.mambio.2008.12.003

Murdoch, J., Buyandelger, S. and Reading, R. (2010c). 'Estimates of toad headed agama density in three steppe habitats of Mongolia'. Erforschung Biologischer Ressourcen der Mongolei (Halle/Saale) 11:383-389.

Murdoch, J., Davie, H., Galbadrah, M., Donovan, T. and Reading, R.P. (2013). 'Do Siberian marmots influence toad -headed agama occupancy? Examining the influence of marmot colonies and three steppe habitats in Mongolia'. Journal of Arid Environments 92:76-80. dx.doi.org/10.1016/j.jaridenv.2013.01.011

Murdoch, J., Davie, H., Galbadrah, M. and Reading, R.P. (2016). 'Factors influencing red fox occupancy probability in central Mongolia'. Mammalian Biology 81: 82-88. dx.doi.org/10.1016/j.mambio.2014.12.001

Reading, R. P., Johnstad, M., Amgalanbaatar, S., Batjargal, Z. and Mix, H. (1999). 'Expanding Mongolia's system of protected areas'. Natural Areas Journal 19(3):211-222.
Reading, R. P., Amgalanbaatar, S., Kenny, D., Onon, Yo., Namshir, Z. and DeNicola, A. (2003). 'Argali ecology in Ikh Nartiin Chuluu Nature Reserve: Preliminary Findings'. Mongolian Journal of Biological Sciences 1(2): 3-14.

Reading, R. P., Amgalanbaatar, S., Wingard, G.J., Kenny, D. and DeNicola, A. (2005a). 'Ecology of argali in Ikh Nartiin Chuluu, Dornogobi Aimag'. Erforschung Biologischer Ressourcen der Mongolei (Halle/Saale) 9: 77-89.

Reading, R. P., Amgalanbaatar, S., Kenny, D. and Dashdemberel, B. (2005b). 'Cinereous vulture nesting ecology in Ikh Nartyn Chuluu Nature Reserve, Mongolia'. Mongolian Journal of Biological Sciences 3(1): 13-19.

Reading, R. P., Amgalanbaatar, S., Kenny, D., DeNicola, A. and Tuguldur, E. (2007). 'Siberian ibex (Capra sibirica) home ranges in Ikh Nart Nature Reserve, Mongolia: preliminary findings'. Mongolia Journal of Biological Sciences 5(1-2):29-37.

Reading, R. P., Kenny, D., Amgalanbaatar, S., DeNicola, A. and Wingard, G. (2009). 'Argali Lamb (Ovis ammon) morphometric measurements and survivorship in Mongolia'. Mammalia 73:98-104. dx.doi.org/10.1515/ MAMM.2009.021

Reading, R. P., Kenny, D., Azua, J., Garrett, T., Willis, M. J. and Tsolmonjav, P. (2010a). 'Ecology of Eurasian black vultures (Aegypius monachus) in Ikh Nart Nature Reserve, Mongolia'. Erforschung Biologischer Ressourcen der Mongolei (Halle/Saale) 11:177-188.

Reading, R. P., Kenny, D., Batdorj, S. and Murdoch, J. (2010b). 'Comparative morphology of two sympatric species of hedgehog in Ikh Nart Nature Reserve, Mongolia'. Erforschung Biologischer Ressourcen der Mongolei (Halle) Saale) 11:323-328.

Reading, R. P., Bedunah, D. J. and Amgalanbaatar, S. (2010c). 'Conserving Mongolia's grasslands with challenges, opportunities, and lessons for America's Great Plains'. Great Plains Research 20(1):85-108.

Reading, R. P., Kenny, D. and Steinhauer-Burkart, B. (2011). Ikh Nart Nature Reserve, 2nd Edition. Oberaula, Germany: Nature-Guide No. 4, Mongolia. ECO Nature Edition Steinhauer-Burkart OHG.

Reading, R. P., Wingard, G., Selenge, T. and Amgalanbaatar, S. (2015). 'The crucial importance of protected areas to conserving Mongolia's natural heritage'. In: G. Wuerthner, E. Crist, and T. Butler (eds.) Protecting the wild: Parks and wilderness, the foundation for conservation), pp. 257-265. Washington, D.C.: Island Press.

Rickinson, M. (2001). 'Learners and learning in environmental education: A critical review of the evidence'. Environmental Education Research 7(3):207-320. dx.doi.org/10.1080/13504620120065230

Sarmento, W. and Reading, R. P. (2016). Conservation presence, not socioeconomics, leads to differences in pastoralist perceived threats to argali. Journal of AsiaPacific Biodiversity 9:263-270. dx.doi.org/10.1016/ j.japb.2016.07.001

Schneider, J.S., Yadmaa, Ts., Hart, T.C, Arlene M., Rosen, A.M. and Spiro, A. (In press). Mongolian "Neolithic" and Early Bronze Age ground stone tools from the northern edge of the Gobi Desert. Journal of Lithic Studies.

Singh, N. J., Amgalanbaatar, S. and Reading, R.P. (2010a). 'Temporal dynamics of group size and sexual segregation in Ibex'. Erforschung Biologischer Ressourcen der Mongolei (Halle/Saale) 11:315-322.

Singh, N. J., Amgalanbaatar, S. and Reading, R.P. (2010b). 'Grouping patterns of argali in Ikh Nart Nature Reserve, Mongolia'. Mongolian Journal of Biological Sciences 8(2): 7-13. 
Tanner, T. (1980). 'Significant life experiences: a new research area in environmental education'. Journal of Environmental Education. 11(4):20-24. dx.doi.org/10.1080/00958964.1980.9941386

Taylor, M. (2015). 'Parks: The best option for wildlife protection in Australia'. In: G. Wuerthner, E. Crist, and T. Butler (eds.) Protecting the wild: Parks and wilderness, the foundation for conservation, pp. 266-276. Washington, D.C.: Island Press.

Terborgh, J. (2015). 'Foreword'. In: G. Wuerthner, E. Crist, and T. Butler (eds.) Protecting the wild: Parks and wilderness, the foundation for conservation, pp. xi-xvii. Washington, D.C.: Island Press.

Tserenbataa, T., Ramey II, R.R., Ryder, O.A., Quinn, T.W. and Reading, R.P. (2004). 'A population genetic comparison of argali sheep (Ovis ammon) in Mongolia using the ND5 gene of mtDNA; Implications for conservation'. Molecular Ecology 13:1333-1339. dx.doi.org/10.1111/j.1365294X.2004.02123.x

Tserendagva, Y., Dalantai, S. and Schneider, J. (2015). Brief Results of the Joint Mongolian-American Expedition for Archaeological Study at Ikh Nart Nature Reserve. Mongolian Archaeology 2014:41-45. (In Mongolian)

Tserendagva, Y., Schneider, J. and Dalantai, S. (2014). Newly Discovered Cave Burials at Ikh Nart. Studia Archaeologica 34:342.

Wingard, G. J., Harris, R. B., Amgalanbaatar, S. and Reading, R. P. (2011a). 'Estimating abundance of mountain ungulates incorporating imperfect detection: Argali in the Gobi
Desert, Mongolia'. Wildlife Biology 17(1):93-101. dx.doi.org/10.2981/10-046

Wingard, G. J., Harris, R. B., Pletscher, D. H., Bedunah, D. J., Bayart, M., Sukh, A. and Reading, R. P. (2011b). 'Argali food habits and dietary overlap with domestic livestock in Ikh Nart Nature Reserve, Mongolia'. Journal of Arid Environments 75(2):138-145. dx.doi.org/10.1016/ j.jaridenv.2010.09.014

Wingard, J. R. and Odgerel, P. (2001). Compendium of environmental law and practice in Mongolia. Ulaanbaatar, Mongolia: GTZ Commercial and Civil Law Reform Project.

Wuerthner, G. (2015). 'Yellowstone as model for the world'. In: G. Wuerthner, E. Crist, and T. Butler (eds.) Protecting the wild: Parks and wilderness, the foundation for conservation, pp. 131-143. Washington, D.C.: Island Press.

Young, J. K., Olson, K.A., Reading, R.P., Amgalanbaatar, S. and Berger, J. (2011). 'Is wildlife going to the dogs? Impacts of feral and free-ranging dogs on wildlife populations'. BioScience 61(2):125-132. dx.doi.org/10.1525/ bio.2011.61.2.7

Zapletal, M., Sodnompil, B., Atwood, J., Murdoch, J. and Reading, R. (2012). 'Home range characteristics and habitat selection by Daurian hedgehogs (Mesechinus dauuricus) in Ikh Nart Nature Reserve'. Mongolian Journal of Biological Sciences 10:41-50.

Zapletal, M., Sodnompil, B., Atwood, J., Murdoch, J. and Reading, R. (2015). 'Fine-scale habitat use by Daurian hedgehogs (Mesechinus dauuricus) in Ikh Nart Nature Reserve, Mongolia'. Journal of Arid Environments 114:100103. dx.doi.org/10.1016/j.jaridenv.2014.11.010

\section{RESUMEN}

Las áreas protegidas representan la forma más eficaz de conservación de la biodiversidad; sin embargo, muchas siguen siendo gestionadas de manera deficiente y otras existen solo en el papel - son los llamados "parques de papel". Describimos nuestros esfuerzos colectivos para transformar la Reserva Natural Ikh Nart (Ikh Nart) en Mongolia de un parque de papel en área protegida modelo. Las limitaciones de recursos y la falta de capacidad impidieron la gestión activa antes de nuestro proyecto. Este artículo describe el proceso que finalmente llevó al Programa de Naciones Unidas para el Desarrollo a designar Ikh Nart como área protegida modelo. Nuestro trabajo incluyó los siguientes cinco aspectos coincidentes y complementarios: 1) una investigación rigurosa; 2) una estructura de gestión con su respectivo plan y proceso; 3) el desarrollo de capacidades locales; 4) la creación de apoyo local; y 5) la creación de políticas de administración y financiación sostenibles. Nuestros esfuerzos propiciaron resultados exitosos, incluyendo la expansión de la reserva, el aumento de las poblaciones de vida silvestre, y un fuerte apoyo local. Las enseñanzas extraídas en el contexto de Ikh Nart pueden ofrecer perspectivas valiosas para el desarrollo de áreas protegidas en otras zonas.

\section{RÉSUMÉ}

Les zones protégées représentent la forme la plus efficace de conservation de la biodiversité; cependant beaucoup restent mal gérées, et certaines, ne bénéficiant d'aucun management, n'existent que sur le papier - d'où l'appellation 'parcs de papier'. Nous décrivons nos efforts collectifs visant à transformer la réserve naturelle de Ikh Nart (Ikh Nart) en Mongolie de 'parc de papier' en aire protégée modèle. Les contraintes de ressources et de capacité ont empêché une gestion active avant notre projet. Le présent document décrit le processus qui a finalement conduit le Programme des Nations Unies pour le Développement à désigner Ikh Nart comme une aire protégée modèle. Notre travail comprend cinq étapes simultanées et complémentaires : 1) lancer un programme de recherche rigoureux ; 2) établir une structure, un plan et un processus de gestion; 3) renforcer les capacités locales ; 4) cultiver le soutien local ; et 5) créer des politiques durables d'administration et de financement. Nos efforts ont abouti à plusieurs réussites, dont notamment l'expansion de la réserve, l'augmentation des populations d'espèces sauvages, et un fort appui local. Les enseignements tirés du cas Ikh Nart pourront fournir des lignes directrices pour le développement des aires protégées dans d'autres parties du monde. 